\title{
FACTORS THAT INFLUENCE THE VIROLOGICAL RESPONSE IN PATIENTS WITH CHRONIC HEPATITIS C TREATED WITH PEGYLATED INTERFERON AND RIBAVIRIN
}

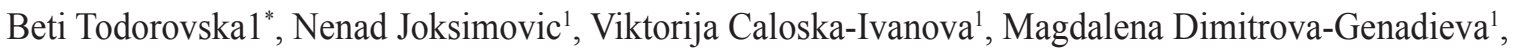
Meri Trajkovska $^{1}$, Elena Curakova ${ }^{1}$, Sanja Kiprijanovska ${ }^{2}$, Beti Zafirova-Ivanovska ${ }^{3}$, Vladimir Serafimoski ${ }^{4}$

${ }^{1}$ University Clinic of Gastroenterohepatology, Faculty of Medicine, University "Ss. Cyril and Methodius", Skopje, Republic of Macedonia

${ }^{2}$ Research Center for Genetic Engineering and Biotechnology "Georgi D. Efremov", Macedonian Academy of Sciences and Arts, Skopje, Republic of Macedonia

${ }^{3}$ Institute of Epidemiology and Biostatistics, Faculty of Medicine, University "Ss. Cyril and Methodius", Skopje, Republic of Macedonia

${ }^{4}$ Macedonian Academy of Sciences and Arts, Skopje, Republic of Macedonia

* Corresponding Author: Beti Todorovska, MD, University Clinic of Gastroenterohepatology, 17, Mother Theresa Str, 1000 Skopje, Republic of Macedonia. Phone: +38976424913 , Fax: +38923147135 Email: todorovskabeti@gmail.com

\section{ABSTRACT}

Introduction: The success of the antiviral treatment in patients with chronic hepatitis $\mathrm{C}$ depends on the factors related to the virus and the host. The aim of the study is the analysis of the antiviral therapy which is a combination of pegylated interferon and ribavirin, considering various factors that will identify the predictors of the sustained virological response. Material and Methods: This retrospective study included 226 patients, divided in two groups. Patients with sustained virological response and patients without sustained virological response were compared in terms of the following factors: genotype, viral load, gender, age, inflammatory and fibrotic changes in the liver, metabolic abnormalities, obesity and fatty liver. Results: The rate of the sustained virological response is $83.6 \%$, more frequently in patients with genotype 3 , with evidenced statistical significance $(90.54 \%)$. The factors that significantly contribute to sustained virological response are related to the age $(p=0.0001)$, genotype $(p=0.002)$, mode of transmission $(p=0.005)$, inflammatory changes in the liver $(p=0.028)$, body mass index $(p=0.022)$ and insulin resistance $(p=0.039)$. The high rate of sustained virological response is related to the younger age of the patients which indirectly means short Hepatitis $C$ Virus infection duration, absence of advanced liver disease and lack of significant co-morbid conditions. Single confirmed independent predictors of sustained virological response are the age (OR 0.928, $\mathrm{p}=0.0001)$ and genotype (OR 3.134, $\mathrm{p}=0.005)$. Conclusions: Factors that are related to the virological response are the age, genotype, mode of transmission, inflammatory changes in the liver, body mass index and insulin resistance, but still, independent predictors of sustained virologic response are the age and the genotype.

Keywords: Chronic viral hepatitis C, pegylated interferon and ribavirin, sustained virological response, predictors of virological response.

\section{INTRODUCTION}

Chronic hepatitis $\mathrm{C}$ is a chronic viral infection that persists for more than six months in more than $75 \%$ of the patients, due to the absence of spontaneous clearance of the virus after an acute infection [1]. This chronic inflammation is responsible for the development of more advanced forms of liver deterioration, resulting in cirrhosis which requires liver transplantation [2]. There is an increased occurrence rate of hepatocellular carcinoma (HCC) associated with this type of infection [3]. The prevalence of the chronic hepatitis $\mathrm{C}$ virus (HCV) infection worldwide is around $2.8 \%$ of the population, which means approximately 185 million people in the world are infected with this disease [4]. There are many ways of transmission of 
the virus, but in Republic of Macedonia, the most common way of HCV transmission is intravenous drug abuse ( $62.3 \%$ of the patients), during hemodialysis treatment (32\% of the patients) and the rest are related to other ways of transmission $(5.7 \%$ of the patients) [5]. The severity of liver damage, as well as the success of the antiviral therapy depend on factors related to the virus (genotype and viremia) and factors related to the host [6]. The most common factors related to the host are the age, gender, genetic variations, alcohol consumption, impact of other toxins, immune status, coinfection with hepatitis B virus (HBV) or human immunodeficiency virus (HIV) infection, metabolic disorders such as increased insulin resistance (IR), obesity, abnormalities in lipid metabolism, fatty liver (steatosis), metabolic syndrome (MS), and others [7-9]. According to the data from the literature, IR is independent of visceral fat tissue, hepatic steatosis and genotype of the virus [10]. There is a negative correlation between the sustained virological response (SVR) and IR, the actually increased IR resulted into lower SVR rate, and vice versa, the higher SVR rate is directly responsible for the reduction of the IR [11]. Hepatitis $\mathrm{C}$ virus uses the host lipid metabolism for its own lifecycle [12]. Impaired lipid metabolism in patients with chronic hepatitis $\mathrm{C}$ infection is determined by the reduction of the total serum cholesterol, LDL, apolipoprotein B and increased steatosis [13]. Obesity, especially trunk thickness is directly related to the increased production of proinflammatory adipocytokine that increases the oxidative stress and weakens the biological response to the treatment regimens based on the interferon therapy [14]. The aim of this retrospective study was to analyze the success of the antiviral therapy in patients with chronic hepatitis $\mathrm{C}$ which comprises a combination treatment with pegylated interferon alpha (peg-IFN alpha-2a or pegIFN alpha-2b) and ribavirin related to various factors (genotype, viral load, the degree of necroinflammatory and fibrotic changes in the liver, gender, age, presence of metabolic abnormalities such as IR, changes in the lipid and glucose profile, presence of obesity and fatty liver) and determination of the SVR predictors.

\section{MATERIAL AND METHODS}

The patients included in this retrospective study, in total 226 , were patients in age over 18 , with verified hepatitis virus $C$ infection [seropositive patients for $\mathrm{HCV}$, as well hepatitis $\mathrm{C}$ virus ribonucleic acid (HCV RNA) positivity confirmed with the polymerase chain reaction (PCR) method]. The patients were hospitalized at the University Clinic of Gastroenterohepatology in Skopje for liver biopsy (one of only two institutions in the country where patients are hospitalized for performing liver biopsy before antiviral treatment) in the period from 2009 to 2015. Most of the data was retrieved from the electronic database of the clinic, and the data related to the genotype and HCV RNA titer, were derived from the Research Centre for Genetic Engineering and Biotechnology "Georgi D. Efremov", Macedonian Academy of Sciences and Arts. The exclusion criteria for this study were: active intravenous drug addicts, positive results for other viruses (HBV or HIV), patients with end-stage renal disease, other etiologies of liver disease (autoimmune hepatitis, diagnosed Wilson's disease, hemochromatosis, patients with primary biliary cirrhosis, primary sclerosant cholangitis, $\alpha 1$ antitrypsin deficiency, patients with decompensate liver disease, previous liver transplantation, alcohol abuse (>20 g/day) and hepatocellular carcinoma. The period of patients treatment depends on the virus genotype: patients with genotype 1 and 4 were treated for period of 48 weeks with pegylated interferon alpha once weekly in subcutaneous dose of $180 \mu \mathrm{g}$ of peg-IFN $\alpha 2 \mathrm{a}$, and the dose of $1.5 \mu \mathrm{g} / \mathrm{kg}$ for peg-IFN $\alpha 2 b$, and for period of 24 weeks for genotype 2 and 3. In addition patients were treated with ribavirinin daily dose of 1,200 mg per os, for genotype 1 and 4, and daily dose of $800 \mathrm{mg}$ per os, for genotypes 2 and 3. The effectiveness of the treatment was confirmed by SVR, indicating undetectable levels of HCV RNA levels 24 weeks after the completion of the antiviral therapy. The patients who have not achieved SVR are considered as Non Virus Responders (NVR). The study was approved by the local Ethics Committee.

The treated 226 patients were analyzed for the following parameters: gender; age; genotype; mode of transmission of the virus (the patients were divided into two groups: group 1 - patients previous intravenous drugs abusers, group 2 - patients infected by the virus via other way of transmission); level of viremia; histological changes in the liver biopsy (i. Knodell scale to determine the degree of inflammation-HAI-histological activity index, graduated from 1 to 18 and ii. fibrosis- the patients are divided into three groups: group 1- no fibrosis, group 2 - fibrosis, and group 3 - liver cirrhosis); steatosis (patients were divided into three groups: group 0 - no steatosis, 1 mild steatosis and group 2 - severe steatosis); body weight expressed as body mass index - BMI (calculated according to the formula: weight in $\mathrm{kg} /$ height $^{2}$ in meters); several laboratory parameters such as: transaminase (aspartate transaminase - AST, alanine aminotransferase - ALT), lipid status (Triglyceride TG, Total Cholesterol, High-Density Lipoprotein Cholesterol - HDL-C, Low-Density Lipoprotein Cholester- 
ol - LDL-C), wherein for dyslipidemia the following cut off ranges referring to the National Cholesterol Education Program Adult Treatment Panel III were determined: $\mathrm{TG} \geq 150 \mathrm{mg} / \mathrm{dL}$ or $\geq 1.7 \mathrm{mmol} / \mathrm{L}$; total cholesterol $\geq 200 \mathrm{mg} / \mathrm{dL}$ or $\geq 5.17 \mathrm{mmol} / \mathrm{L}, \mathrm{LDL}-\mathrm{C}$ $\geq 130 \mathrm{mg} / \mathrm{dL}$ or $\geq 3.36 \mathrm{mmol} / \mathrm{L}$ and HDL-C $<40 \mathrm{mg} /$ $\mathrm{dL}$ or $<1.03 \mathrm{mmol} / \mathrm{L}$ [15], fasting blood glucose and fasting blood insulin, where Homeostasis Model Assessment of Insulin Resistance (HOMA-IR) was calculated according to the formula: fasting insulin $(\mu \mathrm{U}$ / $\mathrm{mL}$ ) x plasma glucose ( $\mathrm{mmol} / \mathrm{L}) / 22.5$.), where the insulin resistance is confirmed when the value is $\geq 2$. In accordance with the virological response the patients were divided into two groups: a group of patients with sustained virological response - SVR and the group of patients Non virus responders - NVR, actually patients who did not have adequate virological response. The above mentioned parameters were compared for those two groups of patients.

Statistical analysis: All data were processed using a statistical computer program SPSS 17 for Windows, where the following statistical tests were used: descriptive statistics (arithmetic mean, standard deviation, standard error, median and inter-quarter interval) for description of the numerical variables, frequencies and percentages for description of the categorical variables. For testing the difference between the numerical variables of the two groups, the Student's T test and Mann-Whitney test were used. For the statistical analysis of the categorical variables the Chi-square test was used. In order to identify the predictors of sustained virological response binary logistic regression analysis was used, by determining the value of the odds ratio (OR) and the $95 \%$ Confidence interval. For all analyzes the $p$ value $<0.05$ was considered statistically significant, and $\mathrm{p}<0.01$ was highly significant.

\section{RESULTS}

The results of our study showed domination of the male subjects (75\%), aged between 18 and 66 years (mean age $33.80 \pm 8.65$ years). The most common way of transmission of the virus was the intravenous drug abuse found in $63 \%$ of the subjects who were former drug abusers (table 1). In our patients the dominant genotype was 3 (present in 67.3\%), followed by genotype 1 (at $31.4 \%$ ), while genotype 2 and 4 were very rare (at $0.9 \%$ and $0.4 \%$ respectively and due to the small number were not suitable for statistical processing). SVR was achieved in $83.6 \%$ of treated patients, and all other baseline characteristics can be seen in Table 1. When the difference of all determined parameters was tested among the group of patients with sustained virological response and the group of Non responders, the following results shown in Table 2 were obtained: SVR was achieved in $85.88 \%$ of the male population and $75.51 \%$ of female population, with no significant difference between the groups in terms of gender $(p=0.0826)$. The patients who did not achieve adequate virological response were older $(40.2 \pm 11.3)$ compared with the group of patients with SVR where the age was $32.5 \pm 7.4$, with evident significance of $\mathrm{p}=0.0001$.

Table 1. Baseline Characteristics of Patients With Chronic Hepatitis C Infection

\begin{tabular}{|c|c|}
\hline Variable & Patients $\mathrm{N}=\mathbf{2 2 6}$ \\
\hline $\begin{array}{l}\text { Sex, } \% \\
\text { Male } \\
\text { female }\end{array}$ & $\begin{array}{l}75 \\
25 \\
\end{array}$ \\
\hline Age, years, mean $\pm \mathrm{SD}$ & $33.80 \pm 8.65$ \\
\hline $\begin{array}{c}\text { Drug abuse, } \% \\
\text { Yes } \\
\text { No }\end{array}$ & $\begin{array}{l}63 \\
37\end{array}$ \\
\hline $\begin{array}{l}\text { Genotype } \% \\
\text { Subtype } 1 \\
\text { Subtype } 2 \\
\text { Subtype } 3 \\
\text { Subtype } 4\end{array}$ & $\begin{array}{c}31.4 \\
0.9 \\
67.3 \\
0.4\end{array}$ \\
\hline $\mathrm{HCV}$ viral load, mean $\pm \mathrm{SD}$ & $1804828 \pm 5031173$ \\
\hline $\begin{array}{l}\text { Knodell Histology Activity Index-HAI, } \\
\text { mean } \pm \text { SD }\end{array}$ & $3 \pm 2$ \\
\hline $\begin{array}{c}\text { Presence of fibrosis, } \% \text { : } \\
\text { No fibrosis } \\
\text { Fibrosis present } \\
\text { Cirrhosis }\end{array}$ & $\begin{array}{c}73.6 \\
21.3 \\
5.1\end{array}$ \\
\hline $\begin{array}{l}\text { Steatosis, \%: } \\
\text { No steatosis } \\
\text { Mild } \\
\text { Severe }\end{array}$ & $\begin{array}{c}55 \\
40 \\
5\end{array}$ \\
\hline $\mathrm{BMI}$, mean $\pm \mathrm{SD}$ & $24.65 \pm 4.21$ \\
\hline $\begin{array}{c}\text { SVR, } \% \\
\text { Yes } \\
\text { No } \\
\end{array}$ & $\begin{array}{l}83.6 \\
16.4 \\
\end{array}$ \\
\hline $\begin{array}{l}\mathrm{AST}(10-34 \mathrm{U} / \mathrm{L}) \\
\text { mean } \pm \mathrm{SD}\end{array}$ & $63 \pm 58$ \\
\hline $\begin{array}{c}\text { ALT }(10-45 \mathrm{U} / \mathrm{L}) \\
\text { mean } \pm \mathrm{SD}\end{array}$ & $97 \pm 86$ \\
\hline Triglyceride $(0.0-2.0 \mathrm{mmol} / \mathrm{L})$, mean $\pm \mathrm{SD}$ & $1.26 \pm 0.75$ \\
\hline Total Cholesterol $(0.0-5.5 \mathrm{mmol} / \mathrm{L})$, mean $\pm \mathrm{SD}$ & $4.23 \pm 1.14$ \\
\hline HDL-C (0.9-2.0 mmol/L), mean \pm SD & $1.16 \pm 0.36$ \\
\hline $\mathrm{LDL}-\mathrm{C}(2.2-3.7 \mathrm{mmol} / \mathrm{L})$, mean $\pm \mathrm{SD}$ & $2.53 \pm 0.97$ \\
\hline Fasting glucose $(3.6-6.5 \mathrm{mmol} / \mathrm{L})$, mean $\pm \mathrm{SD}$ & $5.34 \pm 0.96$ \\
\hline Fasting insulin $(2-17 \mu \mathrm{IU} / \mathrm{ml})$, mean $\pm \mathrm{SD}$ & $12.74 \pm 16.83$ \\
\hline $\mathrm{HOMA} I R$, mean \pm SD & $2.78 \pm 3.55$ \\
\hline
\end{tabular}

Abbreviations: HCV: hepatitis C virus; BMI: body mass index; SVR: sustained virologic response;

ALT: alanine aminotransferase; AST: aspartate transaminase; HDL-C: high-density lipoprotein cholesterol; LDL-C: low-density lipoprotein cholesterol;

HOMA-IR: Homeostasis Model Assessment of Insulin Resistance. 
Table 2. Factors Associated With Virological Response in Patients With Chronic Hepatitis C Infection

\begin{tabular}{|c|c|c|c|}
\hline \multirow[b]{2}{*}{ Variable } & \multicolumn{3}{|c|}{ Response to antiviral therapy } \\
\hline & $\begin{array}{c}\text { SVR } \\
(\mathrm{N}=189)\end{array}$ & $\begin{array}{l}\text { NVRs } \\
(\mathbf{N}=37)\end{array}$ & P value \\
\hline $\begin{array}{l}\text { Sex, No (\%) } \\
\text { Male } \\
\text { female }\end{array}$ & $\begin{array}{c}152(85.88) \\
37(75.51) \\
\end{array}$ & $\begin{array}{l}25(14.12) \\
12(24.49)\end{array}$ & $0.0826 \mathrm{NS}^{1}$ \\
\hline Age, years, mean \pm SD & $32.5 \pm 7.4$ & $40.2 \pm 11.3$ & $0.0001 \mathrm{~S}^{2}$ \\
\hline $\begin{array}{c}\text { Drug abuse, No (\%) } \\
\text { Yes } \\
\text { No } \\
\end{array}$ & $\begin{array}{c}123(90.44) \\
58(72.50) \\
\end{array}$ & $\begin{array}{c}13(9.56) \\
22(27.50) \\
\end{array}$ & $0.005 \mathrm{~S}^{1}$ \\
\hline $\begin{array}{c}\text { Genotype No (\%) } \\
\text { Subtype } 1 \\
\text { Subtype } 2 \\
\text { Subtype } 3 \\
\text { Subtype } 4\end{array}$ & $\begin{array}{c}49(71.01) \\
1(50) \\
134(90.54) \\
1(100)\end{array}$ & $\begin{array}{c}20(28.99) \\
1(50) \\
14(9.46) \\
0(0.00)\end{array}$ & $0.002 \mathrm{~S}^{1}$ \\
\hline $\mathrm{HCV}$ viral load, mean $\pm \mathrm{SD}$ & $1894795 \pm 5422907$ & $1342136 \pm 2057632$ & $0.725 \mathrm{NS}^{3}$ \\
\hline $\begin{array}{c}\text { Liver biopsy } \\
\text { Knodell Histology Activity } \\
\text { Index-HAI, mean } \pm \text { SD }\end{array}$ & $3.176 \pm 2.272$ & $4.258 \pm 2.828$ & $0.028, \mathrm{~S}^{3}$ \\
\hline $\begin{array}{c}\text { Presence of fibrosis, No }(\%) \text { : } \\
\text { No fibrosis } \\
\text { Fibrosis present } \\
\text { Cirrhosis } \\
\end{array}$ & $\begin{array}{c}137(86.16) \\
37(80.43) \\
8(72.73) \\
\end{array}$ & $\begin{array}{l}22(13.84) \\
9(19.57) \\
3(27.27) \\
\end{array}$ & $0.359 \mathrm{NS}^{1}$ \\
\hline $\begin{array}{c}\text { Steatosis, No (\%): } \\
\text { No steatosis } \\
\text { Mild } \\
\text { Severe }\end{array}$ & $\begin{array}{l}75(82.42) \\
53(81.54) \\
8(88.89)\end{array}$ & $\begin{array}{l}16(17.58) \\
12(18.46) \\
1(11.11)\end{array}$ & $0.863 \mathrm{NS}^{1}$ \\
\hline $\mathrm{BMI}$, mean $\pm \mathrm{SD}$ & $24.3 \pm 3.9$ & $26.6 \pm 5.2$ & $0.022, S^{2}$ \\
\hline AST (10-34 U/L), mean \pm SD & $64.9 \pm 62.9$ & $56.0 \pm 24.6$ & $0.708 \mathrm{NS}^{3}$ \\
\hline ALT (10-45 U/L), mean \pm SD & $100.2 \pm 91.4$ & $81.4 \pm 51.6$ & $0.395 \mathrm{NS}^{3}$ \\
\hline Triglyceride $(0.0-2.0 \mathrm{mmol} / \mathrm{L})$, mean $\pm \mathrm{SD}$ & $1.2 \pm 0.7$ & $1.4 \pm 1.03$ & $0.717 \mathrm{NS}^{3}$ \\
\hline Total Cholesterol $(0.0-5.5 \mathrm{mmol} / \mathrm{L})$, mean $\pm \mathrm{SD}$ & $4.3 \pm 1.2$ & $4.1 \pm 0.9$ & $0.655 \mathrm{NS}^{3}$ \\
\hline HDL-C $(0.9-2.0 \mathrm{mmol} / \mathrm{L})$, mean $\pm \mathrm{SD}$ & $1.2 \pm 0.4$ & $1.1 \pm 0.3$ & $0.711 \mathrm{NS}^{3}$ \\
\hline LDL-C (2.2-3.7 mmol/L), mean \pm SD & $2.6 \pm 1.0$ & $2.4 \pm 0.8$ & $0.699 \mathrm{NS}^{3}$ \\
\hline Fasting glucose $(3.6-6.5 \mathrm{mmol} / \mathrm{L})$, mean $\pm \mathrm{SD}$ & $5.2 \pm 0.8$ & $5.9 \pm 1.5$ & $0.02, \mathrm{~S}^{3}$ \\
\hline Fasting insulin $(2-17 \mu \mathrm{IU} / \mathrm{ml})$, mean $\pm \mathrm{SD}$ & $12.6 \pm 17.8$ & $13.3 \pm 9.7$ & $0.037 \mathrm{~S}^{3}$ \\
\hline HOMA-IR, mean \pm SD & $2.7 \pm 3.7$ & $3.1 \pm 2.9$ & $0.039 \mathrm{~S}^{3}$ \\
\hline
\end{tabular}

Abbreviations: SVR: Sustained Virological Response; NVRs: Non Virus Responders; NS: not statistically significant; S: statistically significant;

HCV: hepatitis C virus; BMI: body mass index; AST: aspartate transaminase; ALT: alanine aminotransferase; HDL-C: high-density lipoprotein cholesterol; LDL-C: low-density lipoprotein cholesterol; HOMA-IR: Homeostasis Model Assessment of Insulin Resistance.

${ }^{1}$ Pearson Chi-square

${ }^{2} \mathrm{~T}$ test for independent samples

${ }^{3}$ Mann-Whitney U Test

This evident significance was obtained in relation to the mode of virus transmission, i.e. $90.44 \%$ of patients who were former intravenous drug abusers have achieved SVR, but only $72.5 \%$ of patients who were infected via other virus transmission mode have obtained SVR, or $27.5 \%$ were NVR ( $p=0.005)$. Patients with genotype 3 who have achieved sustained virological response $(90.54 \%)$ were significantly more compared to the patients with genotype 1 $(71.01 \%)$, with significant difference of $p=0.002$. There was no significant difference between the two groups in terms of viral load, where the group with SVR had mean viral load \pm SD $=1894795 \pm$
5422907, min-max (101 - 59159152), median (IQR) $=781164,0(168000-874000)$ and for the group $\mathrm{NVR}$, mean viral load \pm SD was $1342136 \pm 2057632$, $\min -\max (103-7717021)$, median $(\mathrm{IQR})=730000,0$ (103460 -1032037). There was also no significant difference in the presence of fibrosis and steatosis among the groups, but the patients who have not achieved sustained virological response had higher Knodell score-HAI, with a mean value of $4.258 \pm$ 2.828 , compared to those with SVR whose mean value was $3.176 \pm 2.272(p=0.028)$. The greater body weight or higher BMI is an important factor for inadequate virological response so the patients 
Table 3. Binary Logistic Regression Analysis to factors contributing to an SVR in Patients With Chronic Hepatitis C Infection

\begin{tabular}{|c|c|c|c|}
\hline factors & $\mathbf{p}$ - value & OR & $\mathbf{9 5 \%}$ CI for OR \\
\hline Age & $0.0001 \mathrm{~S}$ & 0.928 & $0.890-0.967$ \\
\hline drug users & $0.087 \mathrm{NS}$ & 0.478 & $0.205-1,113$ \\
\hline Genotype & $0.005 \mathrm{~S}$ & 3.134 & $1.416-6.932$ \\
\hline Knodell HAI & $0.053 \mathrm{NS}$ & 0.864 & $0.745-1.002$ \\
\hline BMI & $0.093 \mathrm{NS}$ & 0.909 & $0.813-1.016$ \\
\hline Glicemia & $0.065 \mathrm{NS}$ & 0.705 & $0.486-1.022$ \\
\hline Insulinemia & $0.974 \mathrm{NS}$ & 1 & $0.972-1.028$ \\
\hline HOMA-IR & $0.863 \mathrm{NS}$ & 0.989 & $0.873-1.121$ \\
\hline
\end{tabular}

Abbreviations: SVR: Sustained Virological Response; OR: Odds ratio; 95\% CL: 95\% confidence interval; S: statistically significant; NS: not statistically significant; Knodell HAI: Knodell Histology Activity Index; BMI: body mass index;

HOMA-IR: Homeostasis Model Assessment of Insulin Resistance.

with SVR had a mean BMI of $24.3 \pm 3.9$, while the patients NVR had a BMI of $26.6 \pm 5.2$ or evidenced significance was for $p=0.022$. Mean value of AST and ALT in the SVR group was $64.9 \pm 62.9$ $\mathrm{U} / \mathrm{L}$ and $100.2 \pm 91.4 \mathrm{U} / \mathrm{L}$, respectively, while in the NVR group was $56.0 \pm 24.6 \mathrm{U} / \mathrm{L}$ and $81.4 \pm 51.6$ $\mathrm{U} / \mathrm{L}$, respectively, with no statistical significance. Dyslipidemia was found in $53.8 \%$ of patients, but there was no statistical significance in relation to the dyslipidemia between the groups with SVR and those who do not achieve an adequate response. The baseline total cholesterol and its fractions HDL-C and LDL-C in SVR group was $4.3 \pm 1.2 \mathrm{mmol} / \mathrm{L}$, $1.2 \pm 0.4 \mathrm{mmol} / \mathrm{L}$ and $2.6 \pm 1.0 \mathrm{mmol} / \mathrm{L}$ respectively, while in the NVR group was slightly lower, $4.1 \pm$ $0.9 \mathrm{mmol} / \mathrm{L}, 1.1 \pm 0.3 \mathrm{mmol} / \mathrm{L}$ and $2.4 \pm 0.8 \mathrm{mmol} / \mathrm{L}$ respectively, with no significant difference between groups. The triglycerides were a bit higher in the NVR group $1.4 \pm 1.03 \mathrm{mmol} / \mathrm{L}$, unlike in the SVR group were $1.2 \pm 0.7 \mathrm{mmol} / \mathrm{L}$, but here there was no statistical significance. Unlike lipids, in the glucose status there was a statistical significance of fasting blood glucose, the fasting insulin and the calculated HOMA IR were significantly higher in the group without adequate virological response $(5.9 \pm 1.5$, $13.3 \pm 9.7$ and $3.1 \pm 2.9$ respectively), than in the group with SVR $(5.2 \pm 0.8,12.6 \pm 17.8,2.7 \pm 3.7$ respectively) and the statistical significance was for $p=0.02,0.037$ and 0.039 accordingly. As an information, the insulin resistance was present in $43.6 \%$ of the patients. Using multivariate logistic regression analysis, as independent predictors of sustained virological response, were confirmed only the age of the patients [OR $0.928,95 \% \mathrm{CI}(0.890-0.967), \mathrm{p}=$ 0.0001 ], and the genotype [OR 3.134, 95\% CI (1.416 $-6.932), p=0.005]-$ table 3 . With every additional year of the patient's age, the chances of achieving sustained virological response is reduced by $7.2 \%$.
Patients with genotype 3 have 3.134 times (95\% CI (1.416 - 6.932)) better chances to achieve sustained virological response than patients with genotype 1 .

\section{DISCUSSION}

In Republic of Macedonia, as a country that belongs to the group of developing countries, still the first line treatment of patients with chronic hepatitis $\mathrm{C}$ is combination therapy of pegylated interferon and ribavirin. Our study showed that several factors influence the achievement of sustained virological response, such as: age, mode of virus transmission, genotype, severity of inflammatory changes in the liver, BMI and evidence of glucose abnormalities, actually insulin resistance. There are a number of studies that have made the analysis of a factors associated with SVR, highlighting the predictors of sustained virological response [16,17].

The age is mentioned in several studies as a predictive factor for achieving SVR, whereas older patients have lower rates of SVR versus younger, as confirmed in our study [18]. This factor is highlighted as an independent predictor using multivariate logistic regression analysis in our study that showed less chance for obtaining SVR for 7.2\% after each patient year of age. Despite these, there are studies where age is not a negative predictive factor for sustained virological response, for example the study of Frei et al, (Swiss Hepatitis C Cohort Study Group, 2014), as well as the study of Nishikawa et al. (2012) indicating that interferon combination therapy with ribavirin does not mean inferiority in the elderly and can be safely used in patients with no severe comorbidities $[19,20]$.

Another factor that is highlighted in our study as important for SVR is the way of virus transmission. According to the study of Kiprijanovska et al. 
(2013), in Republic of Macedonia intravenous mode of transmission of HCV through contaminated needles among drug addicts is dominating, found in $62.3 \%$ of patients with hepatitis C, where $64 \%$ of these patients are carriers of genotype 3 [5]. It is important to point out in our study that this group of patients have a very high rate of SVR, even $90.44 \%$, principally due to a number of factors such as: age (it comes to younger patients), genotype (in this group dominates easy to treat genotype 3 ) and evidently less frequent metabolic abnormalities such as disorders in the glucose status which are more common in elderly population. Similar results for former drug addicts who showed a high rate of SVR is evidenced in several other studies including the study of Curelac et al. (2011) [21-24].

Our results showed a high rate of SVR, in the most represented genotypes in our country, genotype 3 and genotype 1 . In $71.01 \%$ of the treated patients with difficult to treat genotype 1 SVR was obtained, and in patients with genotype $3 \mathrm{SVR}$ is evidenced in $90.54 \%$. These values are higher than in other studies where the rate of SVR for genotype 1 is between $40 \%$ and $55 \%$ and for genotype 3 about $80 \%$ [25,26]. Using multivariate logistic regression analysis, the genotype was evidenced as independent predictor of sustained virological response $(p=0.005)$, i.e. patients with genotype 3 have 3.134 times better chance to obtain sustained virological response than patients with genotype 1 . This gives us the right to continue the use of this combination therapy of pegylated interferon and ribavirin, especially in patients with genotype 3 , comparing the high cost of the new group of direct-acting antivirals.

Factors that affect the virological response are necroinflammatory, fibrotic and steatotic deterioration of the liver which in our study have evident significance only for inflammatory activity [27,28]. The fibrotic changes and steatosis were evidenced in more severe form in the group with inadequate virological response, but with no statistical significance.

The occurrence of obesity in recent years is a worrying phenomenon worldwide, both in developed and developing countries and it takes epidemic size as in the USA and Mexico [29]. The overweight expressed through BMI, is determined as important factor which affects the response to antiviral therapy, as confirmed in our study [30].

Lipid metabolism disorder occurs in all patients with chronic hepatitis $\mathrm{C}$ considering the needs of hepatitis $\mathrm{C}$ virus in their development cycle to use the lipids of the host $[31,12,13,32]$. The results of our subjects showed higher values of total cholesterol, including its fractions HDL-C and LDL-C in SVR group, but no significant difference compared with the NVR group, while the level of TG was increased in the NVR group, but also with no evidenced significance in terms of the SVR group, which is also confirmed in other studies [33]. As indicated by some authors, such as Angelico et al. (2009), the higher values of total cholesterol and LDL-C before treatment, favor good therapeutic response, as confirmed in our study [34]. In contrary, the low serum cholesterol may indicate a greater liver damage, progression to fibrosis and adequately poorer response to antiviral therapy.

Changes in glucose metabolism are also often present in patients with chronic hepatitis $\mathrm{C}$, most citing the insulin resistance that eventually could lead to the emergence of diabetes mellitus. Insulin resistance is mentioned in several studies as a factor associated with virological response [35-38]. In the study of Jung et al. (2014), the lower value of HOMA IR was associated with higher SVR rate, but in the group with IR where SVR was obtained, decreasing in HOMA IR after treatment was evidenced [32]. In the study of Romero-Gomez et al. (2005), the insulin resistance, severe fibrosis and genotype 1 are independent predictors of poor virological response [11]. According to the Meta-analysis of Laurito and Parise (2013) where 13 studies with 2238 participating patients were analyzed, it is indicated that IR is associated with a poor virological response, regardless of the genotype [39]. These findings of insulin resistance are confirmed in our study too. Insulin resistance is evidenced in high percentage, i.e. $43.6 \%$ of our patients with hepatitis C, but there are studies that showed a slightly higher value, as in the study of Kiran et al. (2013), where even in 51\% of the analyzed patients with HCV, IR was evidenced [40]. Although, the group of NVR has a statistically higher value of HOMA IR compared with the SVR group, the multivariate analysis showed that IR cannot be considered as predictive factor for SVR.

All these factors noted as important for achieving sustained virological response will support us in future to have an individualized approach to patients with chronic hepatitis C. Particularly important group are the patients with genotype 3 who usually belong to the group of former intravenous addicted to drugs who are also at a younger age, which in our study have evidence of a high percentage of obtained SVR (something above 90\%), so we can treat them with current dual antiviral therapy, a combination of pegylated interferon and ribavirin in the future. For those groups that are difficult to treat (patients with genotype 1 , older patients and those who have more pronounced metabolic abnormalities) the last 
generation of drugs should be taken into account, which in a country like Macedonia are extremely expensive and therefore, not affordable drugs.

\section{CONCLUSION}

Factors that influenced the virological response in our study were the age, the mode of virus transmission, genotype, inflammatory changes in the liver, body mass index and insulin resistance. The rate of sustained virological response is $83.6 \%$, and is statistically significantly more frequent in patients with genotype 3 (90.54\%). This high rate of SVR achieved with combined therapy of pegilated interferon and ribavirin is related to the younger age of the patients which indirectly means short duration of HCV infection, absence of advanced liver disease and lack of significant co-morbid conditions. Independent predictors of SVR in our study are the age and the genotype.

Conflict of Interest: There is no conflict of interest.

\section{REFERENCES:}

1. Micallef JM, Kaldor JM and Dore GJ. Spontaneous viral clearance following acute hepatitis C infection: A systematic review of longitudinal studies. 2006 J. Viral Hepatitis, 13:34-41.

2. Verna EC, Brown RS Jr. Hepatitis $\mathrm{C}$ virus and liver transplantation. Clin Liver Dis 2006;10(4):919-40.

3. Civan J, Hann HW. Hepatitis C Virus Mediated Hepatocellular Carcinoma: A Focused Review for a Time of Changing Therapeutic Options. $N$ A J Med Sci. 2014;7(1):8-16.

4. Hajarizadeh B, Grebely J, Dore GJ. Epidemiology and natural history of HCV infection. Nat Rev Gastroenterol Hepatol 2013; 10: 553-562.

5. Kiprijanovska S, Davalieva K, Novevski P, et al. Prevalence of hepatitis $\mathrm{C}$ virus genotypes in risk groups in the Republic of Macedonia: a 5 years survey. J Med Virol 2013;85(12):2072-8.

6. Samreen B, Khaliq S, Ashfag UA, et al. Hepatitis $\mathrm{C}$ virus entry: role of host and viral factors. Infect Genet Evol. 2012; 12(8):1699-709.

7. Dzekova-Vidimliski P, Nikolov I, Matevska-Geshkovska N, et al. Genetic predictors of the response to the treatment of hepatitis $\mathrm{C}$ virus infection. Bosn J Basic Med Sci 2015; 15(4):55-9.

8. Alberti A. What are the comorbidities influencing the management of patients and the response to therapy in chronic hepatitis C? Liver Int 2009; 29 (Suppl 1): $15-18$.
9. Yu JW, Sun LJ, Liu W, et al. Hepatitis C virus core protein induces hepatic metabolism disorders through down-regulation of the SIRT1-AMPK signaling pathway. Int J Infect Dis 2013; 17(7): e539-45.

10. Bugianesi E, Salamone F, Negro F. The interaction of metabolic factors with $\mathrm{HCV}$ infection:does it matter? Journal of hepatology, 2012; 56(1)S56-S65.

11. Romero-Gomez M, Del Mar Viloria M, Andrade RJ, et al. Insulin resistance impairs sustained response rate to peginterferon plus ribavirin in chronic hepatitis $\mathrm{C}$ patients. Gastroenterology 2005;128:636-641.

12. Grassi G, Di Caprio G, Fimia et al. Hepatitis $\mathrm{C}$ virus relies on lipoproteins for its life cycle. World J Gastroenterol 2016; 22(6): 1953-1965.

13. Bassendine MF, Sheridan DA, Bridge SH, et al. Lipids and HCV. Semin Immunopathol. 2013; 35: $87-100$.

14. Schaffler A, Muller-Ladner U, Scholmerich J, et al. Role of adipose tissue as an inflamatory organ in human disease. Endocr Rev 2006; 27: 449-67.

15. Executive Summary of The Third Report of The National Cholesterol Education Program (NCEP) Expert Panel on Detection, Evaluation, and Treatment of High Blood Cholesterol in Adults (Adult Treatment Panel III). JAMA 2001;285:2486-2497.

16. Wu Q, Zhan FY, Chen EQ, et al. Predictors of Pegylated Interferon Alpha and Ribavirin Efficacy and Long-Term Assessment of Relapse in Patients With Chronic Hepatitis C: A One-Center Experience From China.Hepatitis Monthly. 2015;15(6):e28836.

17. Chuang W-L, Yu M-L. Host factors determining the efficacy of hepatitis $\mathrm{C}$ treatment. Journal of Gastroenterology. 2013;48(1):22-30.

18. Roeder C, Jordan S, Schulze Zur Wiesch J, et al. Age-related differences in response to peginterferon alfa-2a/ribavirin in patients with chronic hepatitis C infection. World J Gastroenterol. 2014;20(31):10984-10993.

19. Frei P, Leucht AK, Held U, et al; Swiss Hepatitis C Cohort Study Group. Elderly age is not a negative predictive factor for virological response to therapy with pegylated interferon- $\alpha$ and ribavirin in chronic hepatitis $\mathrm{C}$ virus patients. Liver Int.2014 Apr;34(4):551-7.

20. Nishikawa H, Iguchi E, Koshikawa Y, et al. The effect of pegylated interferon-alpha2b and ribavirin combination therapy for chronic hepatitis $\mathrm{C}$ infection in elderly patients. BMC Res Notes. 2012;5:135. 
21. Dimova RB, Zeremski M, Jacobson IM, et al. Determinants of hepatitis $\mathrm{C}$ virus treatment completion and efficacy in drug users assessed by meta-analysis. Clin Infect Dis. 2013; 56(6):806-16.

22. Dore G, Hellard M, Matthews G, et al. Effective treatment of injecting drug users with recently acquired Hepatitis C virus infection. Gastroenterology. 2010;138(1):123.

23. Hellard M, Sacks-Davis R, Gold J. Hepatitis C Treatment for Injection Drug Users: A Review of the Available EvidenceClin Infect Dis. (2009) 49 (4): 561-573.

24. Kurelac I, Papic N, Sakoman S, et al. Intravenous Drug Users Can Achieve a High Sustained Virological Response Rate: experience From Croatian Reference Center for Viral Hepatitis. Hepat Mon. 2011;11(12):986-992.

25. European Association for the Study of the L. EASL Clinical Practice Guidelines: management of hepatitis $\mathrm{C}$ virus infection. J Hepatol. 2011;55(2):245-64.

26. Ghany MG, Nelson DR, Strader DB, et al. American Association for Study of Liver D. An update on treatment of genotype 1 chronic hepatitis $C$ virus infection: 2011 practice guideline by the American Association for the Study of Liver Diseases. Hepatology. 2011;54(4):1433-44.

27. Izumi N, Asahina Y, Kurosaki M. Predictors of Virological Response to a Combination Therapy with Pegylated Interferon Plus Ribavirin Including Virus and Host Factors. Hepatitis Research and Treatment. 2010;2010:703602.

28. Patton HM, Patel K, Behling C, et al. The impact of steatosis on disease progression and early and sustained treatment response in chronic hepatitis C patients. J Hepatol 2004;40:484-490.

29. Fierro NA, Gonzalez-Aldaco K, Torres-Valadez $\mathrm{R}$, et al. Immunologic, metabolic and genetic factors in hepatitis C virus infection. World $J$ Gastroenterol 2014; 20(13): 3443-3456.

30. Jonsson JR, Barrie HD, O'Rourke P, et al. Obesity and steatosis influence serum and hepatic inflammatory markers in chronic hepatitis C. Hepatology 2008 Jul;48(1):80-7.
31. Popescu CI, Riva L, Vlaicu O, et al. Hepatitis C Virus Life Cycle and Lipid Metabolism. Biology 2014, 3(4), 892-921.

32. Jung HJ, Kim YS, Kim SG, et al. The impact of pegylated interferon and ribavirin combination treatment on lipid metabolism and insulin resistance in chronic hepatitis $\mathrm{C}$ patients. Clinical and molecular hepatology 2014; 20(1): 38-46.

33. Ramcharran D, Wahed AS, Conjeevaram HS, et al. Virahep-C Study Group. Associations Between Serum Lipids and Hepatitis C Antiviral Treatment Efficacy. Hepatology 2010;52(3):854-63.

34. Angelico F, Francioso S, Del Ben M, et al. Clinical trial: low plasma cholesterol and oxidative stress predict rapid virological response to standard therapy with peginterferon and ribavirin in $\mathrm{HCV}$ patients. Aliment Pharmacol Ther 2009;30, 444-451.

35. Negro F. Steatosis and insulin resistance in response to treatment of chronic hepatitis C. Journal of Viral Hepatitis, 2012, 19 (Suppl. 1), 42-47.

36. Vespasiani-Gentilucci U, Gallo P, De Vincentis $\mathrm{A}$, et al. A. Hepatitis $\mathrm{C}$ virus and metabolic disorder interactions towards liver damage and atherosclerosis. World Journal of Gastroenterology : WJG. 2014;20(11):2825-2838.

37. Enjoji M, Kohjima M, Kotoh K, et al. Metabolic Disorders and Steatosis in Patients with Chronic Hepatitis C: Metabolic Strategies for Antiviral Treatments. International Journal of Hepatology, 2012, Article ID 264017, 7 pages, 2012.

38. Negro F. Facts and fictions of HCV and comorbidities: Steatosis, diabetes mellitus, and cardiovascular diseases. Journal of Hepatology 2014 vol. 61 j S69-S78

39. Laurito MP, Parise ER. Association between insulin resistance and sustained virologic response in hepatitis $\mathrm{C}$ treatment, genotypes 1 versus 2 and 3 : systematic literature review and meta-analysis. Braz J Infect Dis . 2013; 17( 5 ): 555-563.

40. Kiran Z, Zuberi BF, Anis D, et al. Insulin resistance in non-diabetic patients of chronic Hepatitis C. Pak J Med Sci 2013;29(1):201-204. 


\title{
Резиме
}

\section{ФАКТОРИ ШТО ВЛИЈААТ НА ВИРУСОЛОШКИОТ ОДГОВОР КАЈ ПАЦИЕНТИТЕ СО ХРОНИЧЕН ХЕПАТИТИС Ц}

\author{
Бети Тодоровска ${ }^{1 *}$, Ненад Јоксимовиќ ${ }^{1}$, Викторија Чалоска-Иванова ${ }^{1}$, \\ Магдалена Димитрова-Генадиева ${ }^{1}$, Мери Трајковска ${ }^{1}$, Елена Цуракова ${ }^{1}$, \\ Сања Кипријановска ${ }^{2}$, Бети Зафирова-Ивановска ${ }^{3}$, Владимир Серафимоски ${ }^{4}$ \\ ${ }^{1}$ Универзитетска клиника за гастроентерохепатологија, Медицински факултет, \\ Универзитет „Св. Кирил и Методиј“, Скопје, Република Македонија \\ ${ }^{2}$ Истражувачки центар за генетско инженерство и биотехнологија „Георги Д. Ефремов“, \\ Македонската академија на науките и уметностите, Скопје, Република Македонија \\ ${ }^{3}$ Институт за епидемиологија и биостатистика, Медицински факултет, \\ Универзитет „Св. Кирил и Методиј“, Скопје, Република Македонија \\ ${ }^{4}$ Македонската академија на науките и уметностите, Скопје, Република Македонија
}

Boвеg: Успехот на антивирусната терапија кај пациентите со хроничен хепатитис Цзависи од фактори поврзани со вирусот и со домаќинот. Целта на студијата е анализа на успехот на антивирусната терапија со пегилиран интерферон и рибавирин во оваа група пациенти, споредено со различни фактори, кои ќе ги идентификува предикторите на стабилен вирусолошки одговор. Майеријал и мейояи: Во оваа ретроспективна студија се вклучени 226 пациенти, поделени во две групи: група со и група без стабилен вирусолошки одговор, кои се споредувани во однос на следниве фактори: генотип, виремија, пол, возраст, инфламаторни и фиброзни промени на црниот дроб, метаболни нарушувања, обезитас и стеатоза на црниот дроб. Резулйайи: Стапката на стабилен вирусолошки одговор изнесува $83,6 \%$, со сигнфикантно повисока стапка од 90,5\% кај пациентите со генотип 3. Факторите што придонесуваат значително за постигнување стабилен вирусолошки одговор се поврзани со возраста $(\mathrm{p}=0,0001)$, генотипот $(\mathrm{p}=0,002)$, начинот на трансмисија на вирусот $(\mathrm{p}=0,005)$, воспалителните промени во црниот дроб $(\mathrm{p}=0,028)$, телесната маса $(\mathrm{p}=0,022)$ и инсулинската резистенција $(\mathrm{p}=0,039)$. Високата стапка на стабилен вирусолошки одговор се должи на помладата возраст на пациентите, што индиректно значи пократко времетраење на вирусната инфекција, отсуство на напредната црнодробна болест и недостиг на сигнификантни коморбидни состојби. Како независни предиктори на стабилен вирусолошки одговор се потврдија само возраста (OR 0,928, p $=0,0001)$ и генотипот (OR $3,134, p=0,005)$. Заклучок: Фактори што влијаат на виросолошкиот одговор се возраста, генотипот, начин на трансмисија на вирусот, воспалителните промени во црниот дроб, телесната маса и инсулинската резистенција, а како независни предиктори на стабилен вирусолошки одговор се возраста и генотипот.

Клучни зборови: хроничен вирусен хепатитис Ц, пегилиран интерферон и рибавирин, стабилен вирусолошки одговор, предиктори на вирусолошки одговор 